Original Research Article

\title{
Anti asthmatic effect of Momordica Charantia and its comparison with montelukast an in vitro and in vivo model
}

\author{
Bhuvaneswari K.*, Swarna R. M. P. L., Amudhan Aravind
}

Department of Pharmacology, PSG Institute of Medical Sciences and Research,

Peelamedu, Coimbatore 641004, Tamilnadu, India

Received: 06 April 2017

Revised: 13 April 2017

Accepted: 12 June 2017

\section{*Correspondence to: \\ Dr. Bhuvaneswari K., \\ Email: nandabhuvana@ gmail.com}

Copyright: (C) the author(s), publisher and licensee Medip Academy. This is an openaccess article distributed under the terms of the Creative Commons Attribution NonCommercial License, which permits unrestricted noncommercial use, distribution, and reproduction in any medium, provided the original work is properly cited.

\begin{abstract}
Background: Momordica charantia (MC) (bitter gourd) have shown the inhibition of NF- $\kappa \beta$ and Leukotrienes expression in many inflammatory pathological conditions. Based on ist anti-inflammatory action this study aimed to Identify $\mathrm{MC}$ fruit dry powder $(\mathrm{MCp})$ and $\mathrm{MC}$ fresh juice $(\mathrm{MCj})$ action on airway inflammation in Guinea Pig model and also to find out the presence of alkaloids and flavonoides.

Methods: 18 adult Guinea pigs of both sexes (excluding mating animals) were randomly divided into three groups with six animals in each namely Montelukast, $\mathrm{MCj}$ and MCp groups respectively. They were given with OD oral administration of concerned drugs for $1-7$ days. 6 control animals were exposed to $2 \%$ histamine aerosol for 120 seconds using histamine chamber prior to treatment with Montelukast, $\mathrm{MCj}$ and $\mathrm{MCp}$ to observe the normal PreConvulsive Dyspnea (PCD) in seconds. After six hours of daily OD oral dose of test drugs administration, all the groups' were exposed to $2 \%$ Histamine aerosol one by one for $120 \mathrm{sec}$ on day1 \& 7 to observe PCD. The MCj and MCp were also tested with chemical assay, TLC to confirm the presence of alkaloids, flavonoides.

Results: ON DAY 1 and 7: MCj and MCp showed significant decrease in PCD occurrence and it is statistically significant compared to the control. PCD blocking action of $\mathrm{MCj}$ group was effective in DAY 1. TLC and Chemical Assay were not supportive for bronchodilator action.

Conclusions: $\mathrm{MCj}$ and MCp have promising preventive role in asthma. This study had expressed the positive protective role of Momordica charantia in asthmatic condition based on its known anti-inflammatory action.
\end{abstract}

Keywords: Guinea pig, Momordica charantia, Pre-convulsive dyspnea

\section{INTRODUCTION}

Asthma is a controllable chronic inflammatory disorder of the airways with high difficulty to cure completely. ${ }^{1}$ Long term use of anti-inflammatory drugs is the treatment of chronic asthma. Most potent and consistent anti-inflammatory agent available is Corticosteroids and it's not free of adverse effects even in the inhaled form.

As a result, there is continuous search for an alternative especially from natural sources. Momordica Charantia (bitter gourd), a common edible vegetable, is known traditionally to possess medicinal values., ${ }^{2,3}$ Many studies had confirmed the anti-inflammatory property of Momordica Charantia with cytokine inhibiting activity.,5 It inhibited the expression of inflammatory genes like IL1,IL-2,IL-6,IL-8,TNF- $\alpha$ and Matrix Metallo Proteinases (MMPs) in animal studies. ${ }^{6}$ Like Montelukast a Leukotrienes receptor antagonist used in asthma, Momordica Charantia fruit also inhibits NF-K $\beta$ expression. $^{7}$

Very few animal studies were done on its antiinflammatory property utilizing the prostaglandins and inflammatory cytokine inhibition by Momordica Charantia. So far, no study has been done to prove its anti-inflammatory effect in asthma. Hence this study has 
aimed to understand the bronchodilator property of Momordica Charantia as an agent to reduce airway inflammation in a whole animal model using Montelukast as a comparative standard.

\section{METHODS}

\section{Method I: Animal study-histamine induced bronchospasm in guinea pig model}

Animal which used for the study were adult guinea pigs with weight 400-700gram of both sex excluding animals used for breeding.

Period of the study was 15 days to 2 months including animal selection.

Total number of animals were 18 as 3 groups with 6 animals in each.

Study parameters were PCD (Pre-convulsive Dyspnea) per 120 seconds.

Histamine chamber with nebulizer instrument was used with standard technique to apply.

\section{Momordica fruit dry powder and fresh juice}

Momordica Charantia was bought from local farm after getting botanical certification. Then it was used to prepare fresh juice and dry powder after removing seeds.

\section{Fresh juice}

Fresh juice was prepared by using fresh 500gram of $M$. Charantia unripe fruits. Then it was cut into small pieces after removal of the seeds. These fruits were crushed with a commercial blender and juice was obtained after filtration through soft muslin cloth.

\section{Dry powder}

500gram of $M$. Charantia unripe fruits were cut into small pieces after removal of the seeds. These pieces were allowed to dry in hot air oven at 60 degrees for 24 hrs. ${ }^{8}$ Once the fruit pieces were dried enough, they were made into fine powder using blender. Powder thus prepared was passed through a sieve and fine particles was obtained and stored in air tight containers.

\section{IAEC}

The animals were maintained at ambient temperature $25 \pm 2^{\circ} \mathrm{C}$ and $55 \%$ relative humidity. The Institutional Animal Ethics Committee of PSG and IMSR approved the study and the study was conducted strictly with guidelines of ICMR and CPCSEA. 6 animals out of 18, randomly selected to observe the control values for PCD per 120 seconds. Control was exposed to $2 \%$ Histamine aerosol for 120 seconds. $^{7}$ These values were compared with Montelukast, MCp (Momordica Charantia dry powder) and MCj (Momordica Charantia fresh juice) exposure to understand the protective effect on histamine induced Bronchospasm.

If any animals showed severe bronchospasm in any of these groups were immediately exposed to normal air and Inhalational corticosteroid + salbutamol aerosol using nebulizer to revert the histamine induced bronchospasm. After completion of the study, all the animals were observed for a period of 1 week in their own environment with the normal water, food for any reactions.

\section{Method II}

\section{A. Chemical analysis for alkaloid material ${ }^{9}$}

\section{Detection of alkaloids}

Dry powder and Fresh Juice were dissolved individually in dilute Hydrochloric acid was heated for $30 \mathrm{~min}$, allowed to cool and filtered.

- Mayer's Test: Filtrates were treated with Mayer's reagent (Potassium Mercuric Iodide).

- Wagner's Test: Filtrates were treated with Wagner's reagent (Iodine in Potassium Iodide).

- Dragendroff's Test: Filtrates were treated with Dragendroff's reagent (solution of Potassium Bismuth Iodide).

- Hager's Test: Filtrates were treated with Hager's reagent (saturated picric acid solution).

- Marquis test was performed with both dry powder and fresh juice. ${ }^{10}$

1 drop reagent made up of 8-10 drops (approx. $0.25 \mathrm{ml}$ ) of $37 \%$ formaldehyde solution to $10 \mathrm{ml}$ of glacial acetic acid. Then added 3 drops of concentrated sulfuric acid

Results are present in Table 4.

- Chen-Kao Test: Test for ephedrine and pseudoephedrine. $^{10}$

- Reagent 1: Added $1 \mathrm{ml}$ of glacial acetic acid to $100 \mathrm{ml}$ of water $(=1 \%(\mathrm{v} / \mathrm{v})$ aqueous acetic acid solution).

- $\quad$ Reagent 2: Dissolved $1 \mathrm{~g}$ of copper (II) sulphate in $100 \mathrm{ml}$ of water $(=1 \%(\mathrm{w} / \mathrm{v})$ aqueous CuSO4 solution).

- $\quad$ Reagent 3: Dissolved $8 \mathrm{~g}$ of sodium hydroxide in $100 \mathrm{ml}$ of water $(=2 \mathrm{~N}$ aqueous sodium hydroxide solution).

\section{Procedure}

Placed a small amount (1-2 mg of powder, or 1-2 drops of a liquid) of the suspected material in a depression on a spot plate. 
- $\quad$ Added 2 drops of Reagent 1.

- $\quad$ Added 2 drops of Reagent 2 and then added 2 drops of Reagent 3 and stirred. Results were shown in Table 5 .

\section{B. Thin layer chromatography ${ }^{11}$}

MC Dry powder and fresh juice were subjected to thin layer chromatography (TLC) with silica gel F254 plates using Chloroform-Methanol solvent was used and the extract showed spots on Merck silica gel (MSG) precoated TLC plate of thickness of about $0.2 \mathrm{~mm}$.

The plates were saturated in chromatography tank and spots were detected following drying of the solvent. Band of separated fractions was detected under UV light. The retention fraction (Rf) of each fraction or band was calculated and recorded.

\section{Statistical analysis}

Analysis was done by comparing the before and after values, and also between groups student t- test was done for comparing before and after values, whereas ANOVA was used in comparing between all three groups. Analysis was done using SPSS version 19.

\section{RESULTS}

\section{On day 1}

MCj and MCp were showed significant decrease in PCD occurrence and it was statistically significant compared to the control. $\mathrm{MCj}$ group PCD blocking action was significant, when all the three groups were compared (Table 1,2 and 3).

Table 1: Mean+SD of PCD in all three groups in percentage.

\begin{tabular}{|ll|}
\hline Montelukast & $\begin{array}{l}\text { PCD }(120 \mathrm{sec}) \text { in } \% \\
\text { Mean } \pm \text { SD }\end{array}$ \\
\hline Control & $61.10 \pm 9.74$ \\
\hline Day 1 & $79.16 \pm 16.21$ \\
\hline Day 7 & $87.35 \pm 21.16$ \\
\hline Momordica dry powder (MCp) \\
\hline Control & $61.10 \pm 9.74$ \\
\hline Day 1 & $93.47 \pm 12.36$ \\
\hline Day 7 & $93.47 \pm 10.52$ \\
\hline Momordica fresh juice (MCj) \\
\hline Control & $61.10 \pm 9.74$ \\
\hline Day 1 & $73.46 \pm 16.48$ \\
\hline Day 7 & $100.00 \pm 0.00$ \\
\hline
\end{tabular}

\section{On day 7}

MCj and MCp showed significant decrease in PCD occurrence statistically, compared to the control. TLC and chemical assay were not supportive for bronchodilator action (Table 1, 2, 3).

Table 2: $P$ value of PCD in all the three groups.

\begin{tabular}{|c|c|c|c|}
\hline & Between groups & 't' value & P value \\
\hline \multicolumn{4}{|c|}{ PCD (Pre convulsive dyspnoea) } \\
\hline \multirow[t]{3}{*}{ Montelukast } & Control and day 1 & 2.225 & 0.077 \\
\hline & Control and day 7 & 2.521 & 0.053 \\
\hline & Day 1 and day 7 & 0.955 & 0.383 \\
\hline \multirow[t]{3}{*}{ MC powder } & Control and day 1 & 4.187 & 0.009 \\
\hline & Control and day 7 & 5.194 & 0.003 \\
\hline & Day 1 and day 7 & 0.000 & 1.000 \\
\hline \multirow[t]{3}{*}{ MC juice } & Control and day 1 & 2.733 & 0.041 \\
\hline & Control and day 7 & 7.950 & 0.001 \\
\hline & Day 1 and day 7 & 3.176 & 0.034 \\
\hline
\end{tabular}

Table 3: Anova difference between all 3 groups.

\begin{tabular}{|c|c|c|}
\hline \multicolumn{3}{|l|}{ PCD } \\
\hline $\begin{array}{l}\text { Time } \\
\text { period }\end{array}$ & Between group & Significance \\
\hline Day 1 & $\mathrm{MCj}$ is significant over $\mathrm{MCp}$ & $\mathrm{P}=0.037$ \\
\hline Day 7 & $\begin{array}{l}\text { No Significance between all } \\
3 \text { groups }\end{array}$ & $P>0.05$ \\
\hline
\end{tabular}

Table 4: Chemical analysis.

\begin{tabular}{|lll|}
\hline Test for Alkaloids & Dry powder & Fresh juice \\
\hline 1. Mayer's test & Positive & Positive \\
\hline 2. Wagner's test & Positive & Positive \\
\hline 3. Dragendroff's test & Negative & Negative \\
\hline 4. Hager's test & Positive & Positive \\
\hline
\end{tabular}

Table 5: Test for Ephedrine- Marquis test.

\begin{tabular}{|lll|l|}
\hline Compound & $\begin{array}{l}\text { Positive color } \\
\text { reaction }\end{array}$ & $\begin{array}{l}\text { Dry } \\
\text { powder }\end{array}$ & $\begin{array}{l}\text { Fresh } \\
\text { juice }\end{array}$ \\
\hline Ephedrine & Pale yellow & - & - \\
\hline $\begin{array}{l}\text { Pseudoephedrin } \\
\text { e }\end{array}$ & $\begin{array}{l}\text { Pale yellow } \\
\text { (greenish }\end{array}$ & - & - \\
\hline Norephedrine & $\begin{array}{l}\text { Pale yellow } \\
\text { (brownish) }\end{array}$ & - & - \\
\hline $\begin{array}{l}\text { Norpseudo- } \\
\text { ephedrine }\end{array}$ & $\begin{array}{l}\text { Yellow } \\
\text { (brownish) }\end{array}$ & - & - \\
\hline $\begin{array}{l}\text { Norpseudo- } \\
\text { ephedrine }\end{array}$ & $\begin{array}{l}\text { Yellow } \\
\text { (brownish) }\end{array}$ & - & - \\
\hline $\begin{array}{l}N- \\
\text { methylephedrine }\end{array}$ & Brownish red & - & + \\
\hline $\begin{array}{l}\text { Chloropseudo- } \\
\text { ephedrine }\end{array}$ & no change & - & - \\
\hline
\end{tabular}

- Chemical tests: Test for alkaloid and ephedrine were revealed in tabulation (Table 4, 5).

- Chen-Kao test: Test for ephedrine and pseudoephedrine11 - Both dry powder and fresh juice didn't show violet color positive reaction. 
Thin layer chromatography ${ }^{11}$

- Solvent System: Chloroform-Methanol

Detection at UV: $366 \mathrm{~nm}$.

- Color of bands: Reddish spots

Results were shown in the Table 6 and Table 7.

Table 6: Thin layer chromatography.

\begin{tabular}{|ll|l|}
\hline Formulation & No. of spots & Rf value \\
\hline Dry powder (MCp) & 1 & 0.84 \\
\hline Fresh juice $(\mathrm{MCj})$ & 2 & 0.51 \\
\cline { 3 - 3 } & & 0.64 \\
\hline
\end{tabular}

Table 7: TLC of MCj and MCp with atropine and ephedrine.

\begin{tabular}{|ll|l|}
\hline Formulation & No. of spots & Rf value \\
\hline \multirow{2}{*}{ Atropine } & \multirow{2}{*}{3} & 0.1 \\
\hline Ephedrine & 1 & 0.54 \\
\hline Dry powder (MCp) & 1 & 0.6 \\
\hline & & 0.56 \\
\hline Fresh juice (MCj) & 5 & 0.56 \\
\hline & & 0.1 \\
\hline & & 0.54 \\
\hline
\end{tabular}

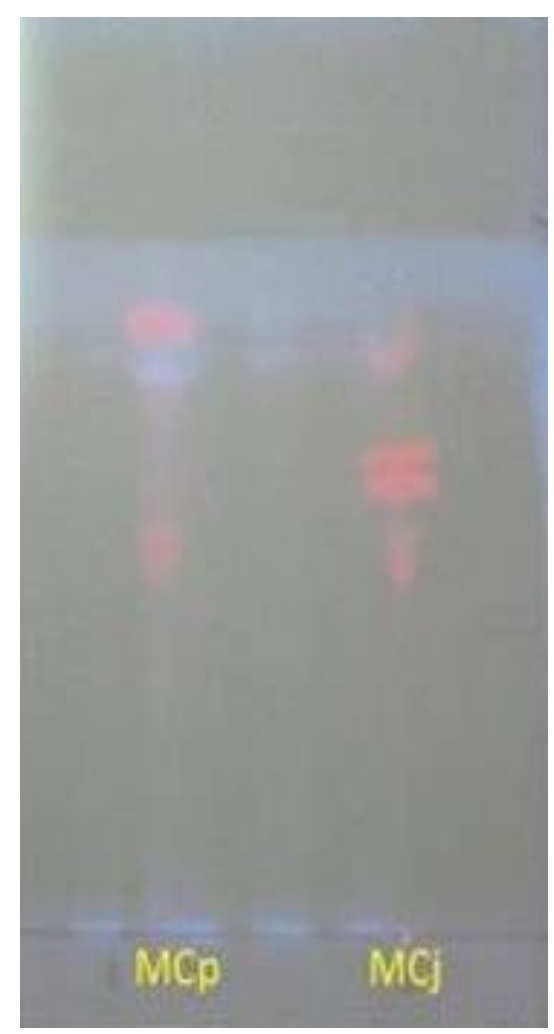

Figure 1: Thin layer chromatography of MCp and $\mathrm{MCj}$.

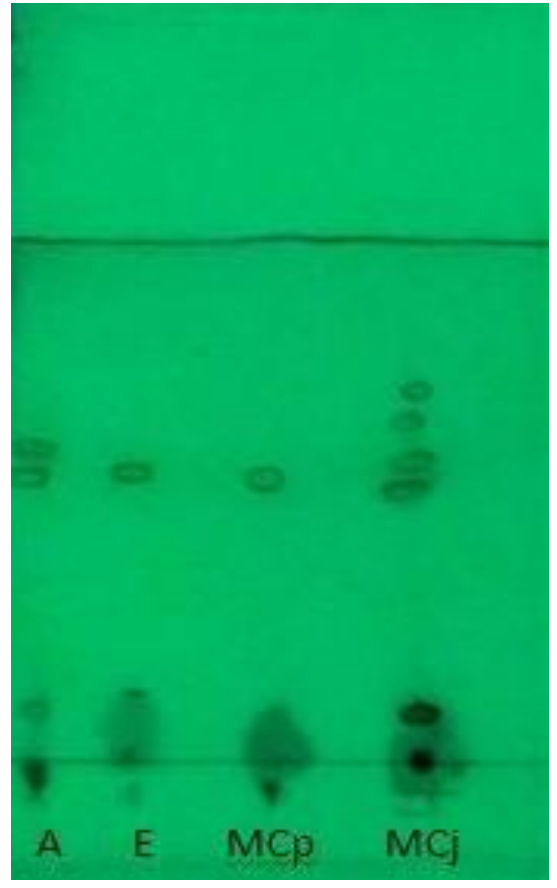

Figure 2: Solvent system: Toluene: Chloroform: Ethanol (28.5:57:14.5) Detection at UV: $254 \mathrm{~nm}$ expressed the presence of A-atropine, E- ephedrine, MCp, MCj.

\section{DISCUSSION}

\section{Pre convulsive dyspneoa}

The mean of the control group was found to be $61.10 \pm$ 9.74 and comparison done for each group with before and after values using student t- test (Table 1).

Montelukast Group compared with the baseline Day 1 control values, the mean was found to be $79.16 \pm 16.21$ which was more than the control mean of $61.1 \%$. But it was not statistically significant with $\mathrm{P}$ value of 0.077 . Day 7 values of Montelukast, the mean was found to be $87.35 \pm 21.16$ and was not statistically significant with $P$ value of 0.053 even though the average PCD was increased from baseline control value on both day 1 and day 7 .

This study also compared the difference between PCD on Day 1 and Day 7. The mean PCD was found to be $79.16 \pm 16.21$ on Day 1 against $87.03 \pm 21.16$ on day 7 . This was also not statistically significant even though there is increase in average value.

MCp group compared for the baseline control value with Day 1 values, mean was found to be $93.47 \pm 12.36$ which was more than the control mean of $61.1 \%$. Also this difference in PCD was statistically significant with $\mathrm{P}$ value of 0.009 which showed the dry powder was effective in delaying PCD. MCp group were compared for Day 7 values, the mean was found to be $93.47 \pm 10.52$. This too was statistically significant with $\mathrm{P}$ value of 0.003 
which proved that the dry powder of Momordica Charantia was effective in delaying PCD in Histamine exposed guinea pigs significantly.

MCp group's were compared for the difference between PCD on Day 1 and Day 7. The mean PCD was found to be $93.47 \pm 12.36$ on Day 1 against $93.47 \pm 10.52$ on day 7 . This was not statistically significant with $\mathrm{P}$ value of 1.000 as there was not much difference in the average value of PCD.

MCj group were compared the baseline Day 1 control value the mean was found to be $73.46 \pm 16.42$ which was more than the control mean of $61.1 \%$. Also this difference in PCD was statistically significant with $\mathrm{P}$ value of 0.041 which shows Fresh juice was effective in delaying PCD. MCj group compared for the Day 7 values, the mean was found to be $100.00 \pm 0.00$. This too was statistically significant with $\mathrm{P}$ value of 0.001 . This proved that the fresh juice of Momordica Charantia was significantly effective in delaying PCD in Histamine exposed guinea pigs.

MCj group compared for the difference between PCD on Day 1 and Day 7, the mean PCD was found to be $73.46 \pm 16.42$ on Day 1 against $100.00 \pm 0.00$ on day 7 . This was statistically significant with $\mathrm{P}$ value of 0.034 which justifies Momordica was effective in both short term and long-term management.

Further analysis of both study groups of Momordica dry powder and fresh juice with student t-test. On day 1 in dry powder group the mean was found to be $93.47 \pm 12.36$ and in fresh juice group it was found to be $73.46 \pm 16.42$. This was statistically significant with $\mathrm{P}$ value of 0.038 ; which showed the dry powder was better on Day 1 of treatment with quick response. On day 7 in dry powder group the mean was found to be $93.47 \pm 10.52$ whereas in fresh juice group it was $100.00 \pm 0.00$. This was not statistically significant as both groups had similar protective effect on day 7 . The average was more in fresh juice group compared to the dry powder group on day 7 .

When ANOVA was used to analyze the difference between the groups, (Table 2) on Day 1, MCp was significantly better than $\mathrm{MCj}$ with $\mathrm{P}$ value of 0.037 whereas it was not statistically better than Montelukast. On day 7, there was no statistical significance between all 3 groups since all were effective in abolishing PCD occurrence.

These results showed that, there was a significant improvement in both groups of Momordica after starting treatment, whereas there was no much difference between groups. It's a pilot study and each group strength was six may be the limitation of this study.

Momordica charantia had been extensively studied for various metabolic, antihypertensive and its role in Diabetes with its anti-inflammatory background and not much significant reference for the direct effect of $\mathrm{MC}$ on smooth muscle activity. ${ }^{12-15}$

\section{CONCLUSION}

This study had expressed the positive protective role of Momordica charantia in asthmatic condition based on its known anti-inflammatory action. Further, MC both dry powder and fresh juice protecting role on histamine aerosol induced bronchospasm as an anti asthmatic action may be explored and proved in clinical situation using suitable models to ensure the usefulness and effectiveness in chronic asthma treatment compared to standard care of management in future.

\section{ACKNOWLEDGMENTS}

Authors would like to thank PSG Institutions Management for providing the infrastructures including financial assistance to proceed and complete this study. Authors thank the Dean, PSG IMS and R and Hospitals, The Principal, PSG College of Pharmacy for their kind technical support to complete this study. Also thank all the technicians, lab assistants of Department of Pharmacology PSG IMS and R for their countless help in performing this Research.

Funding: Funding sources from PSG IMS and R Conflict of interest: None declared

Ethical approval: The study was approved by the Institutional Ethics Committee

\section{REFERENCES}

1. Global Initiative for Asthma. Global stargery for asthma management and prevention, 2017. Available from: www.ginasthma.org [Accessed ${ }^{\text {st }}$ May 2017]

2. Pharmacological actions and potential uses of Momordica charantia: a review 9 jEthnopharmacol. 2004;93(1):123-32.

3. Kumar SKP, Bhowmik D. Traditional Medicinal Uses and Therapeutic Benefits of Momordica Charantia Linn. International Journal of Pharmaceutical Sciences Review and Research. 2010;4(3):23-8.

4. Mariko M, Ryo T, Teruko N. Induction of Antiinflammatory Responses by Dietary Momordica charantia L. (Bitter Gourd) Biosci. Biotechnol. Biochem. 2003;67(12):2512-7.

5. Nguyen, Pham, Nguyen, Tran, Phan, Chau. Inhibition of Nuclear Transcription Factor-jBand Activation of Peroxisome Proliferator-Activated Receptors in HepG2 Cells by Cucurbitane-Type Triterpene Glycosides from Momordica Charantia. J Med Food. 2012;15(4):369-77.

6. Chao C, Sung P, Wang W, Kuo Y. AntiInflammatory Effect of Momordica Charantia In Sepsis Mice. Molecules. 2014;19:12777-88.

7. Sridevi G, Gopkumar P, Ashok S, Shastry C. Pharmacological Basis For Antianaphylactic, 
Antihistaminic and Mast Cell Stabilization Activity of Ocimum Sanctum. The Internet J Pharmacol. 2009;7(1).

8. Singh U, Sagar VR. Effect of drying methods on nutritional composition of dehydrated bitter gourd (Momordica Charantia.). Indian Agricultural Research Institute, New Delhi-12. Agriculture for Sustainable Development. 2013;1(1):83-6.

9. Tiwari P, Kumar B, Kaur M, Kaur G, Kaur H. Phytochemical screening and extraction: a review. Internationale pharmaceutica sciencia. 2011 Mar;1(1):98-106.

10. Nagy G, Szöllősi I, Szendrei K. Colour Tests for Precursor Chemicals of Amphetamine-Type substancesthe Use of Colour Tests for Distinguishing between Ephedrine-Derivatives un scientific and technical notes. Scitec; 2005:16-17.

11. Abalaka ME, Inabo HI, Onaolapo JA, Olonitola OS. Chromatographic Analysis and Antibacterial Effects of the Ethanolic Extracts of Momordica Charantia. Afr J Med Phy, Biomed Eng and Sc. 2010;2:14-20.
12. Tsai CH, Chen EC, Tsay HS, Huang CJ. Wild bitter gourdimproves metabolic syndrome: a preliminary dietary supplementationtrial. Nutr J. 2012;11:4.

13. Klomann SD, Mueller AS, Pallauf J, Krawinkel MB. Antidiabeticeffects of bitter gourd extracts in insulinresistant db/db mice. BrJ Nutr. 2010;104:1613-20.

14. Virdi J, Sivakami S, Shahani S, Suthar AC, Banavalikar MM, Biyani MK. Antihyperglycemic effects of three extracts from Momordica Charantia. J Ethnopharmacol. 2003;88:107-11.

15. Fuangchan A, Seubnukarn T, Jungpattanawadee D, Sonthisombat P, Ingkaninan K, Plianbangchang P, et al. Retrospective study on the use of bitter melon for type 2 diabetes at Dansai Crown Prince Hospital, Thailand. Srinagarind Med J. 2009;24:332-8.

Cite this article as: Bhuvaneswari $\mathrm{K}$, Swarna RMPL, Amudhan A. Anti asthmatic effect of Momordica Charantia and its comparison with montelukast an in vitro and in vivo model. Int J Basic Clin Pharmacol 2017;6:1810-5. 